\title{
EGYETEMI TANÁRI PÁLYÁZATOK MINIMÁLIS PUBLIKÁCIÓS KÖVETELMÉNYEINEK VÁLTOZÁSA ÉS VÁRHATÓ HATÁSA A TÁRSADALOMTUDOMÁNYOK TERÜLETÉN
}

\author{
SASVÁRI PÉTER ${ }^{\mathrm{a}, *}$ - LUDÁNYI BRIGITTA ${ }^{\mathrm{b}, \mathrm{c}}$ \\ aNemzeti Közszolgálati Egyetem Államtudományi és Nemzetközi Tanulmányok Kar, \\ Közszervezési és Infotechnológiai Tanszék \\ ${ }^{\mathrm{b}}$ ELTE Nyelvtudományi Doktori Iskola \\ 'Nemzeti Közszolgálati Egyetem Tudományos Ügyek Iroda \\ Beérkezett: 2020. szeptember 4., elfogadva: 2021. május 18.
}

Az egyetemi tanári pályázat összeállításához és értékeléséhez összeállított, a Magyar Akkreditációs Bizottság által elfogadott módosított útmutató 2020. szeptember 1-jétől lépett hatályba. A módosított követelményrendszer vizionálja a jelenlegi értékmérők átalakulását. A tudományos teljesítmény súlypontjaivá a folyóirat-publikációk váltak, azonban a hazai közlemények önmagukban nem elegendőek, a nemzetközi láthatóság és minőségi rangsor feltétele a nemzetközi publikálás, amely egyúttal a tudományos fokozatok elérésének is feltételévé vált. Jelen tanulmány a gazdaságtudomány, valamint a társadalomtudományok területén müködő magyarországi egyetemek oktatóinak publikációs tevékenységén keresztül vizsgálja a módosított követelményrendszer hatását és következményeit az egyetemi tanári pályázat, valamint tágabb értelemben a nemzetközi tudományos elismertség vonatkozásában.

Kulcsszavak: Magyar Akkreditációs Bizottság, egyetemi tanári pályázat, követelményrendszer, társadalomtudományok, folyóirat-publikáció

The modified Guidelines for the Compilation and Evaluation of the Applications for the Position of University Full Professors approved by the Hungarian Accreditation Committee was to enter into force on the 1 st of September in 2020. The reshaped re-

\footnotetext{
* Levelező szerző: Sasvári Péter, Nemzeti Közszolgálati Egyetem, Államtudományi és Nemzetközi Tanulmányok Kar, Közszervezési és Infotechnológiai Tanszék, 1083 Budapest, Üllői út 82.

E-mail: sasvari.peter@uni-nke.hu
} 
quirement system envisions the transformation of current assessment criteria. Journal publications have become the focus of scientific performance, however, publications in domestic journals alone are not enough; apart from being required for achieving international scientific visibility and quality ranking, international publications have also become a prerequisite for scientific degrees. The present study examines the impact and consequences of the modified requirement system on university professorships and, in a broader sense, on their international scientific recognition through the publication activities of lecturers from Hungarian universities in the fields of Economics and social sciences.

Keywords: Hungarian Accreditation Committee, application for the position of University Full Professor, requirement system, social sciences, journal publications

\section{Bevezetés}

A nemzetközi tudományos tér egyre több szereplőt vonz maga köré, ezáltal pedig a siker és elismertség egyre inkább a folyóirat-publikációs teljesítmény függvénye (Wuchty-Jones-Uzzi 2007). Ma már nem elég kizárólag hazai tudományos közleményeket publikálni, mert az egyre nagyobb versenyben a digitális eszközök segítségével a még áttekinthetőbbé váló világban nemzetközi rangsorképző feltétel a nemzetközi publikációs teljesítmény. A pályázati alapú finanszírozás modellje Magyarországon is egyre nagyobb teret nyer a tudományos fokozatok ranglétrájának bármelyik fokán. Ez az újfajta finanszírozási rendszer egyrészt eredményorientáltságot, másrészt a rendszeres és átlátható értékelési rendszerek által értékelt nemzetközi és hazai kutatói és oktatói kiválóságot, valamint az erőforrásokért és támogatásért folytatott harcot vár el a magyar felsőoktatási rendszer valamennyi intézményétől és alkalmazottjától (Kozma 2011).

A magyar tudományos rendszerben részt vevők mind fokozataikban, mind munkaköri beosztásukban teljesítményüktől és egyéni érdemeiktől függően léphetnek előre. A tudományos lépcsőfokokat a PhD-fokozat megszerzése (Kiss 2014), majd a habilitáció (Dobos-Michalkó-Nováky 2016; Sasvári-Urbanovics 2019), a Magyar Tudományos Akadémia (a továbbiakban: MTA) doktori fokozat (Zalai 2006), végül pedig az akadémikusi szint (MTA rendes és levelező tagja) testesíti meg (Polónyi 2010). Érdemi szakmai szelekció a Magyar Akkreditációs Bizottság (a továbbiakban: MAB) egyetemi tanári véleményezési és az MTA doktori pályázati rendszerben érvényesül (Bazsa 2017). A felsőoktatásban a munkaköri beosztások ezekkel párhuzamosan szintén emelkednek, melyek sorban egyetem esetén a tanársegéd, adjunktus, egyetemi docens és egyetemi tanári szintek (Sasvári-Urbanovics 2019). Az egyetemi tanári a hazánkban megszerezhető legmagasabb beosztás a felsőoktatási intézményekben, tudományos közegben.

2020 júniusában a MAB az egyetemi tanári pályázatokra vonatkozó módosított útmutatót fogadott el (MAB 2020), mely 2020. szeptember 1-jén lépett hatályba. Az útmutatóval kapcsolatban érdemes megemlíteni, hogy az nem az MTA tudományos bizottságai szerint, hanem tudományterületi besorolás szerint határozza meg a követelményeket. Az egyetemi tanári pályázatok esetében eddig is e tudományterületi 
besorolás volt a mértékadó. Az útmutató minimális, általános és speciális feltételeket egyaránt megfogalmaz, többek között a felsőoktatási és a tudományos tevékenység tekintetében is. A határozat elöremutató követelményrendszere a nemzetközi tudományos közösségben végbemenő jelentős folyamatok sorába illeszkedik, melyek a jelenlegi értékmérők teljes átalakulásához vezetnek. Jelen tanulmány célja a módosított 2020-as útmutató folyóiratcikkekre vonatkozó követelményeinek bemutatása, továbbá az, hogy a gazdaságtudomány, valamint a társadalomtudományok területén müködő magyarországi egyetemek oktatóinak publikációs tevékenységén keresztül megvizsgálja a módosított követelményrendszer hatását és következményeit az egyetemi tanári pályázat, valamint tágabb értelemben a nemzetközi tudományos elismertség vonatkozásában.

\section{Elméleti háttér}

A 2020 szeptemberétől életbe lépő módosított egyetemi tanári MAB-os szabályozás megengedi a társadalom- és gazdaságtudomány területén kutatók számára, hogy a Q1-es és Q2-es cikkek és monográfiák mellett, illetve helyett az MTA nemzetközi A és B kategóriájú listás folyóiratcikkeket is benyújtsanak a pályázatuk összeállítása során.

A módosított útmutató az alábbiak szerint tartalmazza a minimális elvárásokat: „a minimális elvárás, hogy a pályázó legalább két idegen nyelvü, szakterületi szempontból releváns területen megjelent Q1-es vagy Q2-es, vagy az MTA tudományterületi nemzetközi folyóiratjegyzéke $A$, illetve $B$ kategóriájába tartozó cikk, vagy legalább egy elismert nemzetközi kiadó által kiadott monográfia szerzöje legyen." (MAB 2020: 13.)

A minimális publikációs feltételeket három lehetséges módon lehet teljesíteni:

1. Az első lehetséges út a Scimago Journal Rank (SJR) nemzetközi folyóiratrangsor szerinti minősített folyóiratcikkek írása. Fontos eleme az átállásnak, hogy a folyóiratok (ezen keresztül pedig a cikkek) SJR-értékük szakterületi kategórián belüli rangsora alapján négy, azonos méretű osztályba sorolva jelennek meg, a rangsor felső 25\%-ától kezdve a rangsor végén elhelyezkedő $25 \%$-kal bezárólag. Ez az ún. kvartilis-besorolás (Q1: legjobb 25\%; Q2: 25-50\%; Q3: 50-75\%; Q4: 75-100\%) teszi lehetővé, legalábbis elvileg, hogy a különböző tudomány- és szakterületekhez tartozó folyóiratok és cikkek közvetlenül (vagyis a saját területükön elfoglalt pozíciójuk alapján) összemérhetők legyenek (Soós 2017). Egy folyóiratcikk különböző tudománykategóriában eltérő Q-s besorolással rendelkezhet. Ilyenkor a legmagasabb besorolást azonosítjuk a közleménnyel.

2. Az MTA IX. Gazdaság- és Jogtudományok Osztálya (GJO) eredetileg e két nagy tudományterület akadémikus tagjainak testületeként jött létre. Az MTA doktora tudományos cím megszerzéséért indított eljárásban testületként járnak el a GJO tudományos/doktori szakbizottságai, amelyek a következők: Állam-és Jogtudományi Bizottság (ÁJB), Gazdaságtudományi Minősítő Bizottság (GMB), Hadtudományi Bizottság (HTB), Nemzetközi és Fejlődéstanulmányok Doktori Bizottság (NFDB), Politikatudományi Bizottság (PTB), Regionális Tudományok Bizottsága (RegTB), Szociológiai Tudományos Bizottság (SZTB), a demográfiát érintő doktori ügyekben vagy a Szociológiai Tudományos Bizottság vagy a Gazdaságtudományi Minősítő Bizottság a Demográfiai Osztályközi Állandó Bizottság (DEM) doktor tagjaival kiegészítve dönt. A szakbizottságok folyóiratlistái, a folyóirat megcélzott szakmai 
közönsége (szerzők és olvasók) és nemzetközi ismertsége szerint két kategóriát különböztetnek meg: nemzetközi és hazai folyóiratokat, melyeket négy kategóriába (A, B, C és $\mathrm{D}$ kategória, ahol az A kategória a legjelentősebb, a D pedig a legkevésbé jelentős) sorolnak. A GJO listás rangsorolás határozott előnye, hogy lehetővé teszi olyan nemzetközi szakfolyóiratok minőségi értékelését, amelyek nagyrészt kiesnek a nemzetközi adatbázisok - Scopus, Web of Science - hatásköréből. Ilyen kategorizált listával csak a GJO rendelkezik, amely lefedi a MAB szerint értelmezett társadalom- és gazdaságtudományt. Egy folyóiratcikk különböző bizottsági listákon, eltérő $\mathrm{ABCD}$-s besorolással rendelkezhet.

3. A harmadik lehetséges út egy elismert nemzetközi kiadó által kiadott monográfia írása. A monográfiára jellemző, hogy egy önálló dolgozat, szakmai írásmű, amely egy tudományos kérdést minden szempontból, kimerítően, egységbe foglalva tárgyal. Az értékelő lapok közül a gazdaságtudományra vonatkozó tartalmaz egy listát, amely megmondja, hogy mely kiadó tekinthető „elismertnek” (lásd a Melléklet 1. táblázat).

Tehát a módosított verzió minimális publikációk tekintetében egyfelől könnyítést jelent a pályázók számára a GJO nemzetközi lista bevonásával; másfelől pontosítást jelent a gazdaságtudomány területén, mivel rámutat, hogy mely könyvkiadók könyvei fogadhatók el.

A nemzetközi GJO listás folyóiratok bizottságonként vannak felosztva. Az alábbi bizottságoknak van folyóiratlistájuk: ÁJB, GMB, HTB, NFDB, PTB, RegTB, SZTB és DEM. Minden bizottsági lista A, B, C és D kategóriás folyóiratokat tartalmaz. Egy folyóirat szerepelhet egy vagy több nemzetközi GJO-s bizottsági listán. A bizottságok megállapodtak abban, hogy legalább D kategóriás besorolással elfogadják a másik bizottság listáján szereplő folyóiratcikket.

\section{A kutatás menete}

Elemzésünket a társadalom- és gazdaságtudományi területen müködő 21 magyarországi felsőoktatási intézmény 41 olyan karára, illetve intézetére terjesztettük ki, melyek foglalkoznak társadalom- és gazdaságtudománnyal. A karokat/intézeteket 3 csoportba soroltuk tevékenységük alapján:

1. Állam-, jog-, nemzetközi- és rendészettudományi karok (10 darab): 1. Eötvös Loránd Tudományegyetem, Állam- és Jogtudományi Kar (ELTE-ÁJK); 2. Nemzeti Közszolgálati Egyetem, Államtudományi és Nemzetközi Tanulmányok Kar (NKE-ÁNTK); 3. Szegedi Tudományegyetem, Állam- és Jogtudományi Kar (SZTE-ÁJK); 4. Debreceni Egyetem, Állam- és Jogtudományi Kar (DE-ÁJK); 5. Pécsi Tudományegyetem, Állam- és Jogtudományi Kar (PTE-ÁJK), 6. Miskolci Egyetem, Állam- és Jogtudományi Kar (ME-ÁJK); 7. Pázmány Péter Katolikus Egyetem, Jog-és Államtudományi Kar (PPKE-ÁJK); 8. Károli Gáspár Református Egyetem, Állam- és Jogtudományi Kar (KRE-ÁJK); 9. Nemzeti Közszolgálati Egyetem, Rendészettudományi Kar (NKE-RTK); 10. Széchenyi István Egyetem, Deák Ferenc Állam- és Jogtudományi $\operatorname{Kar}(\mathrm{SZE}-\mathrm{DFK})$.

2. Közgazdaság- és gazdaságtudományi karok (23 darab): 1. Budapesti Corvinus Egyetem, Gazdálkodástudományi Kar (BCE-GTK); 2. Budapesti Corvinus Egyetem, Közgazdaságtudományi Kar (BCE-KTK); 3. Szent István Egyetem, Gazdaság- és 
Társadalomtudományi Kar (SZIE-GTK); 4. Debreceni Egyetem, Gazdaságtudományi Kar (DE-GTK); 5. Pécsi Tudományegyetem, Közgazdaságtudományi Kar (PTE-KTK); 6. Budapesti Műszaki és Gazdaságtudományi Egyetem, Gazdaság- és Társadalomtudományi Kar (BME-GTK); 7. Szegedi Tudományegyetem, Gazdaságtudományi Kar (SZTE-GTK); 8. Budapesti Gazdasági Egyetem, Pénzügyi és Számviteli Kar (BGE-PSZK); 9. Pannon Egyetem, Gazdaságtudományi Kar (PE-GTK); 10. Széchenyi István Egyetem, Kautz Gyula Gazdaságtudományi Kar (SZE-GK); 11. Eötvös Loránd Tudományegyetem, Gazdálkodástudományi Intézet (ELTEGTI); 12. Budapesti Metropolitan Egyetem, Üzleti, Kommunikációs és Turisztikai Kar (METU-ÜKT); 13. Miskolci Egyetem, Gazdaságtudományi Kar (ME-GTK); 14. Kaposvári Egyetem, Gazdaságtudományi Kar (KE-GTK); 15. Eszterházy Károly Egyetem, Gazdaság- és Társadalomtudományi Kar (EKE-GTK); 16. Óbudai Egyetem, Keleti Károly Gazdasági Kar (OE-KGK); 17. Budapesti Gazdasági Egyetem, Kereskedelmi, Vendéglátóipari és Idegenforgalmi Kar (BGE-KVIK); 18. Budapesti Gazdasági Egyetem, Gazdálkodási Kar Zalaegerszeg (BGE-GKZ); 19. Budapesti Gazdasági Egyetem, Külkereskedelmi Kar (BGE-KKK); 20. Soproni Egyetem Lámfalussy Sándor Közgazdaságtudományi Kar (SOE-LKK); 21. Gál Ferenc Főiskola, Gazdasági Kar (GFF-GK); 22. Neumann János Egyetem, Gazdaságtudományi Kar (NJE-GTK); 23. Szent István Egyetem, Agrár- és Gazdaságtudományi Kar (SZIE-AGK).

3. Társadalom-, bölcsész- és hadtudományi karok (8 darab): 1. Eötvös Loránd Tudományegyetem, Társadalomtudományi Kar (ELTE-TÁTK); 2. Budapesti Corvinus Egyetem, Társadalomtudományi és Nemzetközi Kapcsolatok Kar (BCE-TK); 3. Nemzeti Közszolgálati Egyetem, Hadtudományi és Honvédtisztképző Kar (NKEHHK); 4. Pázmány Péter Katolikus Egyetem, Bölcsészet- és Társadalomtudományi Kar (PPKE-BTK); 5. Szegedi Tudományegyetem, Bölcsészet- és Társadalomtudományi Kar (SZTE-BTK); 6. Pannon Egyetem, Modern Filológiai és Társadalomtudományi Kar (PE-MFTK); 7. Károli Gáspár Református Egyetem, Bölcsészet- és Társadalomtudományi Kar (KRE-BTK); 8. Miskolci Egyetem, Bölcsésztudományi $\operatorname{Kar}(\mathrm{ME}-\mathrm{BTK})$.

A vizsgálatba bevont karok és intézetek publikációs teljesítményükkel kapcsolatos adataikat a Magyar Tudományos Művek Tárából (a továbbiakban: MTMT) töltöttük le, mely egy országos bibliográfiai adatbázis, melynek használata és folyamatos frissítése minden tudományos pozíciót betöltő kutató számára jogszabályi kötelezettség (A Magyar Tudományos Akadémiáról szóló 1994. évi XL. törvény). Csak azokat a közleményeket tudtuk vizsgálni, amelyek az adott felsőoktatási intézményhez voltak rendelve. A GJO listás nemzetközi A, B, C és D kategóriás folyóiratcikkeket, valamint a Q1-es, a Q2-es, a Q3-as és Q4-es cikkeket az MTMT rendszerből nyertük ki.

\section{Kutatási eredmények}

A vizsgált intézmények kutatói 1281 darab SJR Q-s folyóiratcikket és 657 darab GJO nemzetközi listás közleményt publikáltak 2017 és 2018 között. A 657 GJO listás közlemény 63\%-a (414 darab) SJR Q-s közlemény, a maradék 37\% (243 darab) nem az. 


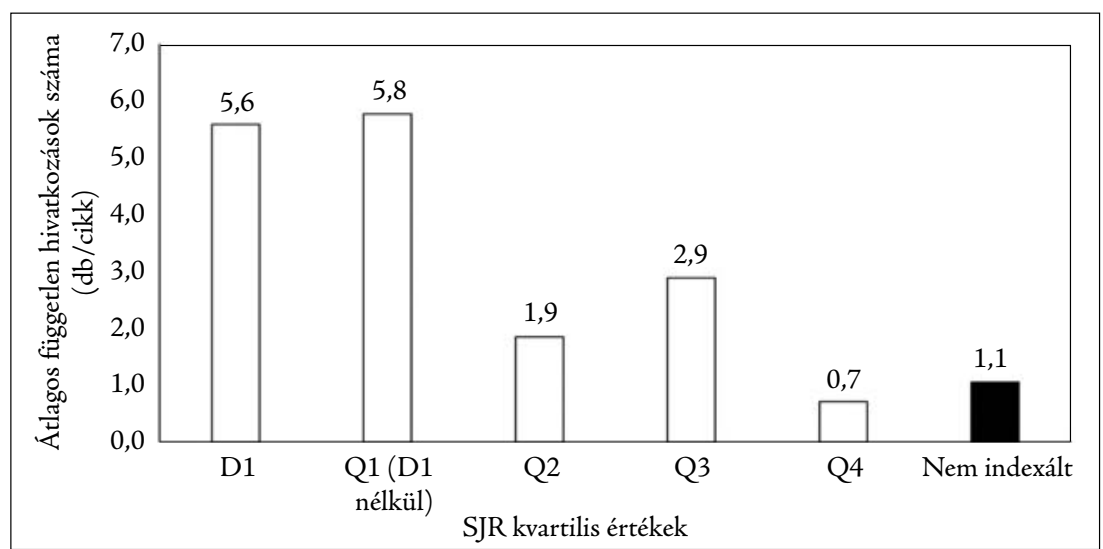

1. ábra: A GJO listás közlemények átlagos független hivatkozásainak alakulása. Forrás: MTMT

A GJO listás közleményekre 1777 darab független hivatkozás érkezett 2019-ig, melynek 85\%-a (1520 darab) olyan folyóiratcikkre érkezett, amely a GJO mellett SJR Q-s besorolással bírt. Az 1. ábra jól mutatja, hogy a legnagyobb átlagos hivatkozásokkal a D1-es (felső decilis) és a Q1-es közlemények (átlagosan 5,6, illetve 5,8 darab/cikk) bírnak.

A vizsgált karok kutatói tehát SJR listás Q-s és GJO listás folyóiratokban is publikálnak. Azt, hogy melyik kar oktatói mennyit publikálnak, elsősorban az befolyásolja, hogy az adott szervezetben hányan dolgoznak, és az intézmény/kar melyik tudományterületen tevékenykedik. Ez alapján három csoportba sorolhatók a vizsgált intézmények/karok (2. ábra):

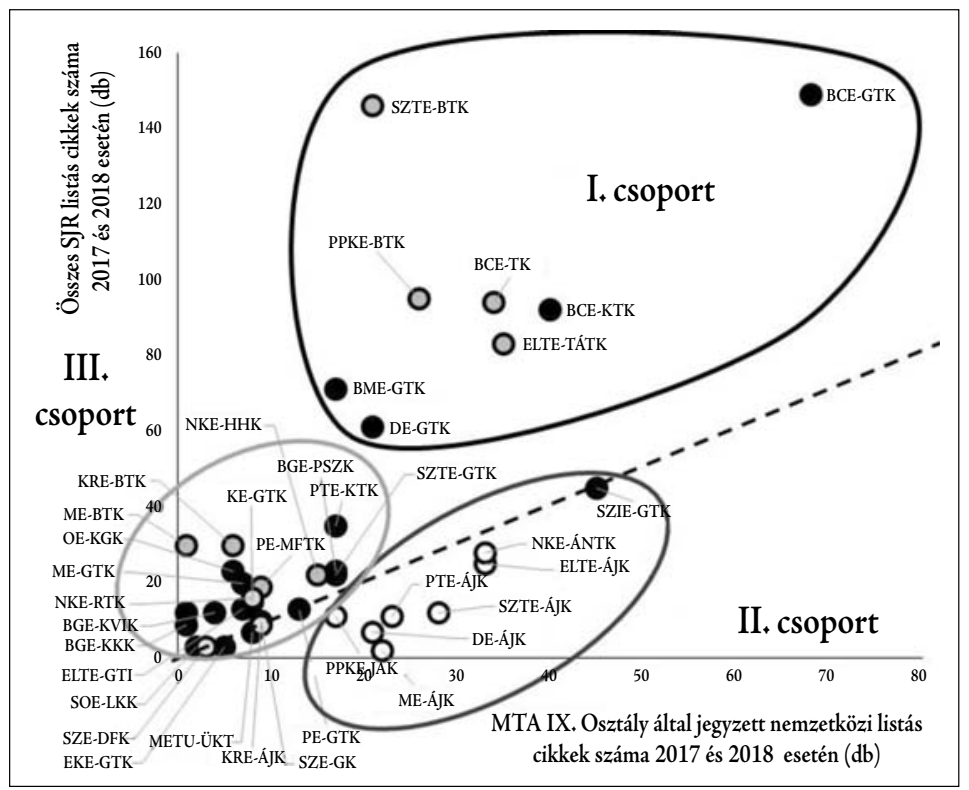

2. ábra: Nemzetközi GJO és SJR listás cikkek számainak összevetése a vizsgált karoknál 2017-ben és 2018-ban. Forrás: MTMT 


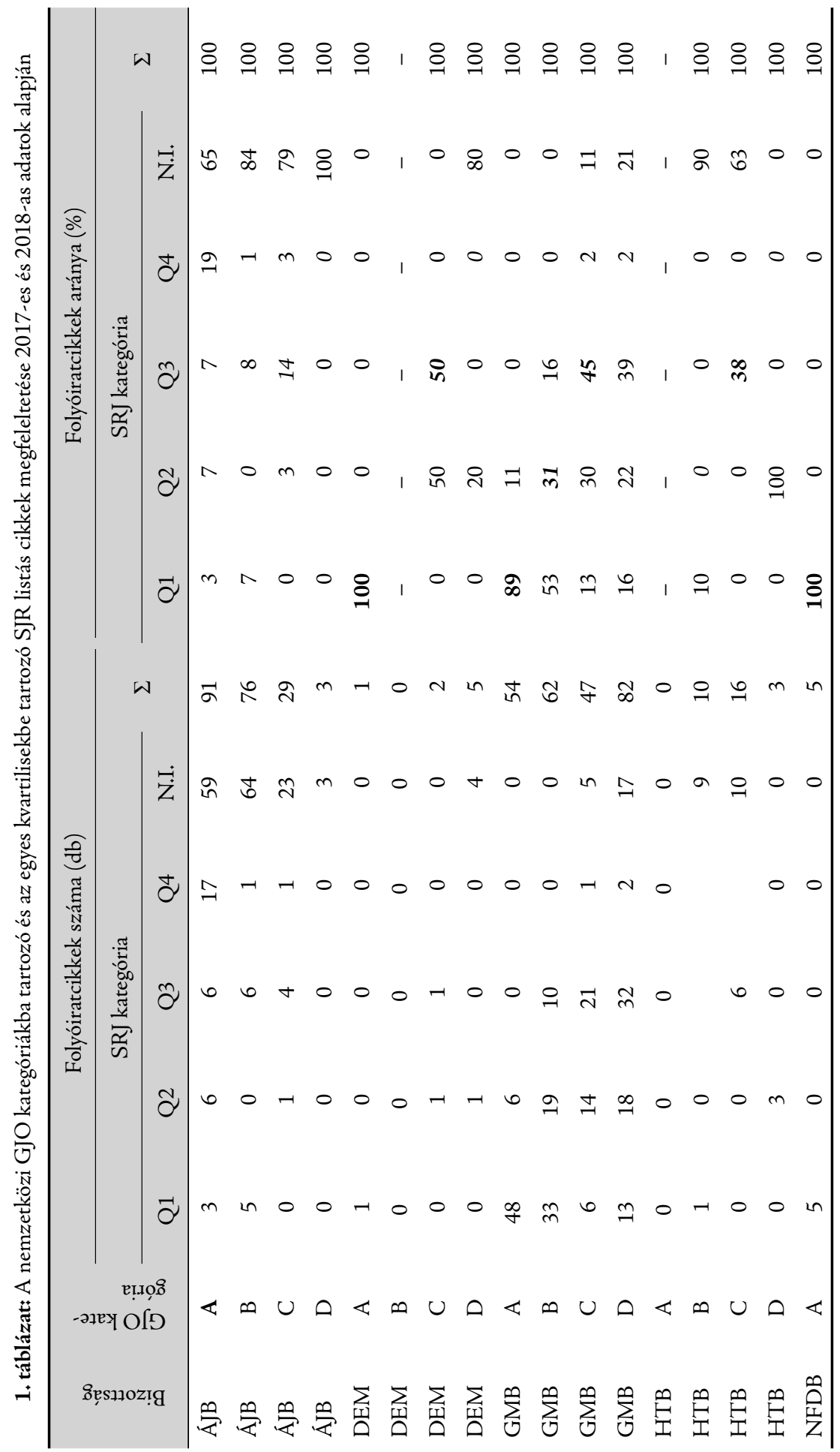


— SASVÁRI P. - LUdÁNYI B.: EGYETEMI TANÁRI PÁLYÁZATOK MINIMÁliS PUBLIKÁCIÓS...

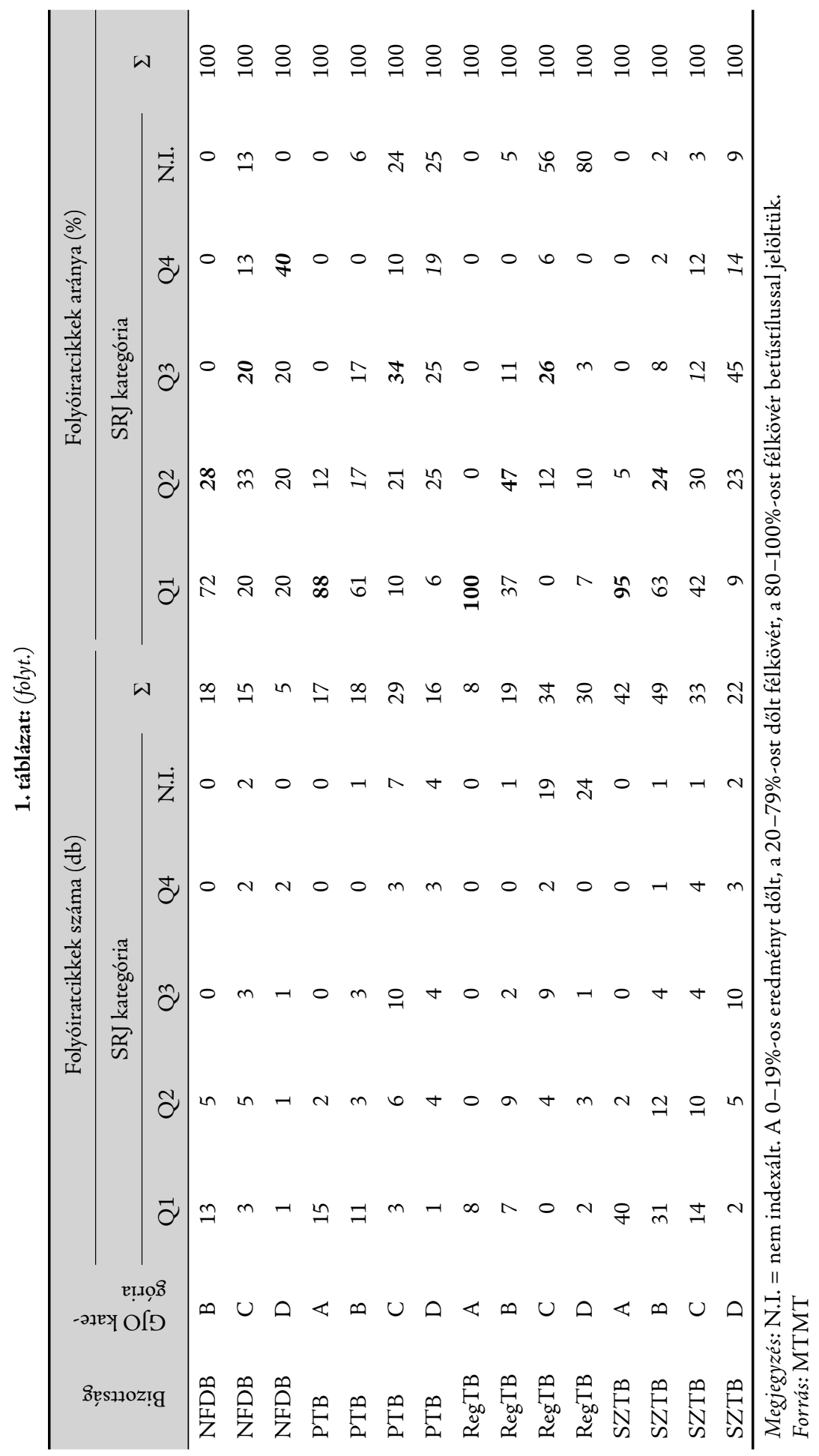


I. csoport, ahol nagyobb számban SJR listás cikkeket, kisebb arányban GJO listás közleményeket publikálnak. Ebbe a csoportba 4 gazdaságtudománnyal (BCEGTK, BCE-KTK, DE-GTK és BME-GTK) és 4 társadalomtudománnyal (SZTEBTK, PPKE-BTK, BCE-TK és ELTE-TÁTK) foglakozó kar található.

II. csoport, ahol nagyobb számban GJO listás közleményeket, kisebb arányban SJR listás folyóiratcikkeket publikálnak. Itt 8 egyetemi kart találunk, melyek közül 7 (NKE-ÁNTK, ELTE-ÁJK, PTE-ÁJK, SZTE-ÁJK, DE-ÁJK, PPKE-JAK és MEÁJK) elsődlegesen az ÁJB listát használja és egy (SZIE-GTK) RegTB listát használ.

III. csoport, ahol a GJO listás és SJR listás közlemények száma igen alacsony. Ez részben magyarázható az intézmény méretével, illetve az orientáltság hiányával. Itt a maradék 25 kart találjuk.

2. táblázat: Állam-, jog-, nemzetközi és rendészettudományi karok nemzetközi GJO listás közleményei folyóiratonként 2017-ben és 2018-ban

\begin{tabular}{|c|c|c|c|c|c|c|}
\hline $\begin{array}{l}\text { Sor- } \\
\text { szám }\end{array}$ & Folyóirat neve & $\begin{array}{l}\text { Kiadó } \\
\text { országa }\end{array}$ & $\begin{array}{l}\text { GJO } \\
\text { kategória }\end{array}$ & $\begin{array}{l}\text { Legjobb } \\
\text { kvartilis } \\
\text { 2018-ban }\end{array}$ & $\begin{array}{l}\text { SJR lis- } \\
\text { tás cikk } \\
(\mathrm{db})\end{array}$ & $\begin{array}{l}\text { Nem SJR } \\
\text { listás cikk } \\
\text { (db) }\end{array}$ \\
\hline 1 & $\begin{array}{l}\text { JOURNAL ON EURO- } \\
\text { PEAN HISTORY OF } \\
\text { LAW }^{*}\end{array}$ & $\begin{array}{l}\text { Cseh- } \\
\text { ország }\end{array}$ & ÁJB „A" & Q4 & 15 & 15 \\
\hline 2 & CURENTUL JURIDIC & Románia & ÁJB „B” & - & 0 & 15 \\
\hline 3 & $\begin{array}{l}\text { ZBORNIK RADOVA } \\
\text { PRAVNI FAKULTET } \\
\text { (NOVI SAD) }\end{array}$ & Szerbia & ÁJB „B” & - & 0 & 14 \\
\hline 4 & LEX ET SCIENTIA & Románia & ÁJB „A" & - & 0 & 7 \\
\hline 5 & $\begin{array}{l}\text { EUROPEAN REVIEW } \\
\text { OF PUBLIC LAW }\end{array}$ & $\begin{array}{l}\text { Nagy- } \\
\text { Britannia }\end{array}$ & ÁJB „A" & - & 0 & 6 \\
\hline 6 & OSTEUROPA-RECHT & $\begin{array}{l}\text { Német- } \\
\text { ország }\end{array}$ & ÁJB „B” & - & 0 & 6 \\
\hline 7 & $\begin{array}{l}\text { ECONOMICS \& } \\
\text { WORKING CAPITAL }\end{array}$ & $\begin{array}{l}\text { Nagy- } \\
\text { Britannia }\end{array}$ & ÁJB „B” & - & 0 & 5 \\
\hline 8 & $\begin{array}{l}\text { JOURNAL OF EAST- } \\
\text { ERN-EUROPEAN } \\
\text { CRIMINAL LAW }\end{array}$ & Románia & ÁJB „C" & - & 0 & 5 \\
\hline 9 & PRAVNI VJESNIK & $\begin{array}{l}\text { Horvát- } \\
\text { ország }\end{array}$ & ÁJB „C" & - & 0 & 5 \\
\hline 10 & $\begin{array}{l}\text { JAHRBUCH FÜR } \\
\text { OSTRECHT }\end{array}$ & $\begin{array}{l}\text { Német- } \\
\text { ország }\end{array}$ & ÁJB „A" & - & 0 & 4 \\
\hline 11 & Egyéb & - & - & - & 36 & 61 \\
\hline & \multicolumn{4}{|l|}{ Folyóiratcikkek száma (db) } & 51 & 143 \\
\hline & \multicolumn{4}{|l|}{ Folyóiratcikkek aránya (\%) } & $26 \%$ & $74 \%$ \\
\hline
\end{tabular}

Megjegyzés: *2019-től Scopus által indexált lett. Rövidités: ÁJB = Állam- és Jogtudományi Bizottság.

Forrás: MTMT 
Felmerül a kérdés, hogy a GJO egyes kategóriába (A, B, C, D) tartozó cikkek hova tartoznak az SRJ kategóriái (Q1, Q2, Q3, Q4) szerint. Másképp fogalmazva: megfeleltethetö-e például a Q1-es cikk az A, a Q2-es a B, a Q3-as a C és a Q4-es a D kategóriás cikknek? Az 1. táblázat alapján látható, hogy az $\mathrm{A}$ kategóriához tartozó Q1-s cikkek aránya 80-100\% közé esik bizottsági listától függetlenül, a $\mathrm{B}$ a Q2-vel, a C a Q3-mal 20-79\%-ban, a D a Q4-gyel pedig 0-19\%-ban van fedésben. Az is látható, hogy az ÁJB lista esetén egyik kategória esetében sincs számottevő átfedés, míg a többi bizottsági lista esetében megjelenik bizonyos mértékü megfeleltethetőség, melynek mértéke - mint

3, táblázat: Társadalom-, bölcsészet- és hadtudományi karok nemzetközi GJO listás közleményei folyóiratonként 2017-ben és 2018-ban

\begin{tabular}{|c|c|c|c|c|c|c|}
\hline $\begin{array}{l}\text { Sor- } \\
\text { szám }\end{array}$ & Folyóirat neve & $\begin{array}{l}\text { Kiadó } \\
\text { országa }\end{array}$ & $\begin{array}{l}\text { GJO } \\
\text { kategória }\end{array}$ & $\begin{array}{l}\text { Legjobb } \\
\text { kvartilis } \\
\text { 2018-ban }\end{array}$ & $\begin{array}{l}\text { SJR lis- } \\
\text { tás cikk } \\
\text { (db) }\end{array}$ & $\begin{array}{l}\text { Nem SJR } \\
\text { listás cikk } \\
\text { (db) }\end{array}$ \\
\hline 1 & $\begin{array}{l}\text { FRONTIERS IN } \\
\text { PSYCHOLOGY }\end{array}$ & Svájc & SZTB„B” & Q1 & 9 & 0 \\
\hline 2 & $\begin{array}{l}\text { SCIENTIFIC RE- } \\
\text { PORTS }\end{array}$ & $\begin{array}{l}\text { Nagy- } \\
\text { Britannia }\end{array}$ & SZTB„B” & Q1 & 7 & 0 \\
\hline 3 & $\begin{array}{l}\text { ZEITSCHRIFT FÜR } \\
\text { PAPYROLOGIE UND } \\
\text { EPIGRAPHIK }\end{array}$ & $\begin{array}{l}\text { Német- } \\
\text { ország }\end{array}$ & ÁJB „A" & Q2 & 5 & 0 \\
\hline 4 & $\begin{array}{l}\text { REVISTA ACADEMIEI } \\
\text { FORTELOR TERESTRE }\end{array}$ & Románia & HTB „B” & - & 0 & 4 \\
\hline 5 & $\begin{array}{l}\text { VALUE IN HEALTH } \\
\text { REGIONAL ISSUES }\end{array}$ & $\begin{array}{l}\text { Egyesült } \\
\text { Államok }\end{array}$ & GMB „D” & Q1 & 4 & 0 \\
\hline 6 & DEATH STUDIES & $\begin{array}{l}\text { Egyesült } \\
\text { Államok }\end{array}$ & SZTB „B” & Q2 & 3 & 0 \\
\hline 7 & $\begin{array}{l}\text { GERMAN LAW } \\
\text { JOURNAL }\end{array}$ & $\begin{array}{l}\text { Német- } \\
\text { ország }\end{array}$ & ÁJB „B” & - & 0 & 3 \\
\hline 8 & PLOS ONE & $\begin{array}{l}\text { Egyesült } \\
\text { Államok }\end{array}$ & $\mathrm{SZTB}, \mathrm{A}^{\prime}$ & Q1 & 3 & 0 \\
\hline 9 & $\begin{array}{l}\text { CENTRAL EURO- } \\
\text { PEAN PAPERS }\end{array}$ & $\begin{array}{l}\text { Cseh- } \\
\text { ország }\end{array}$ & ÁJB „C" & - & 0 & 2 \\
\hline 10 & COLD WAR HISTORY & $\begin{array}{l}\text { Nagy- } \\
\text { Britannia }\end{array}$ & $\begin{array}{l}\text { SZTB, „C” } \\
\text { NFDB,C” } \\
\text { PTB „B” }\end{array}$ & Q2 & 2 & 0 \\
\hline \multirow[t]{3}{*}{11} & Egyéb & - & - & - & 90 & 15 \\
\hline & Folyóiratcikkek száma (db) & & & & 123 & 24 \\
\hline & Folyóiratcikkek aránya (\%) & & & & $84 \%$ & $16 \%$ \\
\hline
\end{tabular}

Megjegyzés: 2019-től Scopus által indexált lett. Rövidités: ÁJB = Állam- és Jogtudományi Bizottság, GMB = Gazdaságtudományi Doktori Minősítő Bizottság, HTB = Hadtudományi Bizottság, NFDB = Nemzetközi és Fejlődéstanulmányok Doktori Bizottság, PTB = Politikatudományi Bizottság, SZTB = Szociológiai Tudományos Bizottság.

Forrás: MTMT 
4, táblázat: Közgazdaság- és gazdaságtudományi karok nemzetközi GJO listás közleményei folyóiratonként 2017-ben és 2018-ban

\begin{tabular}{|c|c|c|c|c|c|c|}
\hline $\begin{array}{l}\text { Sor- } \\
\text { szám }\end{array}$ & Folyóirat neve & $\begin{array}{l}\text { Kiadó } \\
\text { országa }\end{array}$ & $\begin{array}{l}\text { GJO } \\
\text { kategória }\end{array}$ & $\begin{array}{l}\text { Legjobb } \\
\text { kvartilis } \\
\text { 2018-ban }\end{array}$ & $\begin{array}{l}\text { SJR lis- } \\
\text { tás cikk } \\
(\mathrm{db})\end{array}$ & $\begin{array}{l}\text { Nem SJR } \\
\text { listás cikk } \\
\text { (db) }\end{array}$ \\
\hline 1 & DETUROPE & Szerbia & RegTB „C” & Q3 & 4 & 10 \\
\hline 2 & $\begin{array}{l}\text { VISEGRAD JOURNAL } \\
\text { ON BIOECONOMY } \\
\text { AND SUSTAINABLE } \\
\text { DEVELOPMENT }\end{array}$ & Szlovákia & RegTB „D” & - & 0 & 13 \\
\hline 3 & $\begin{array}{l}\text { REGIONALNAJA } \\
\text { EKONOMIKA: } \\
\text { JUG ROSSII }\end{array}$ & $\begin{array}{l}\text { Orosz- } \\
\text { ország }\end{array}$ & RegTB „D” & - & 0 & 9 \\
\hline 4 & $\begin{array}{l}\text { FINANCE RESEARCH } \\
\text { LETTERS }\end{array}$ & Hollandia & GMB „C” & Q1 & 7 & 0 \\
\hline 5 & $\begin{array}{l}\text { JOURNAL OF } \\
\text { CLEANER } \\
\text { PRODUCTION }\end{array}$ & Hollandia & GMB „A” & Q1 & 6 & 0 \\
\hline 6 & $\begin{array}{l}\text { CENTRAL EURO- } \\
\text { PEAN JOURNAL } \\
\text { OF OPERATIONS } \\
\text { RESEARCH }\end{array}$ & Svájc & GMB „B” & Q2 & 5 & 0 \\
\hline 7 & $\begin{array}{l}\text { ECONOMIC } \\
\text { ANNALS-XXI }\end{array}$ & Ukrajna & SZTB„D” & Q3 & 5 & 0 \\
\hline 8 & $\begin{array}{l}\text { ECONOMICS \& } \\
\text { WORKING CAPITAL }\end{array}$ & $\begin{array}{l}\text { Nagy- } \\
\text { Britannia }\end{array}$ & ÁJB „B” & - & 0 & 4 \\
\hline 9 & $\begin{array}{l}\text { ECONOMICS AND } \\
\text { SOCIOLOGY }\end{array}$ & $\begin{array}{l}\text { Lengyel- } \\
\text { ország }\end{array}$ & SZTB „C" & Q1 & 4 & 0 \\
\hline 10 & $\begin{array}{l}\text { EUROPE-ASIA } \\
\text { STUDIES }\end{array}$ & $\begin{array}{l}\text { Nagy- } \\
\text { Britannia }\end{array}$ & $\begin{array}{l}\text { SZTB „A” } \\
\text { RegTB,,B” } \\
\text { NFDB,B” } \\
\text { PTB „A" }\end{array}$ & Q1 & 4 & 0 \\
\hline \multirow[t]{3}{*}{11} & Egyéb & - & - & - & 237 & 76 \\
\hline & Folyóiratcikkek száma (db) & & & & 272 & 112 \\
\hline & Folyóiratcikkek aránya (\%) & & & & $71 \%$ & $29 \%$ \\
\hline
\end{tabular}

Megjegyzés: 2019-től Scopus által indexált lett. Rövidités: ÁJB = Állam-és Jogtudományi Bizottság, GMB = Gazdaságtudományi Doktori Minősítő Bizottság, NFDB = Nemzetközi és Fejlődéstanulmányok Doktori Bizottság, $\mathrm{PTB}=$ Politikatudományi Bizottság, RegTB = Regionális Tudományok Bizottsága, SZTB = Szociológiai Tudományos Bizottság.

Forrás: MTMT

ahogy az előbbiekben láthattuk - a folyóirat besorolásától függ. Az 1. táblázat szumma oszlopa összesen 841 cikket ad ki, holott korábban 657 darab GJO nemzetközi listás közleményről írtunk, ami egy közlemény több bizottsági listán való részvételére utal, azaz vannak átfedések a bizottsági listák között. 
A 2017-es és 2018-as évekre vonatkozóan, az elemzésbe vont felsőoktatási intézményeknél megvizsgáltuk a nemzetközi folyóiratcikkek számát, amiből jól látható, hogy az Állam-és jogtudományok területén a szerzők szívesebben választják azokat a GJO által felsorolt A, B, C és D listás folyóiratokat, amelyek nem SJR Q-sak (2. táblázat). Ennek a valószínűsíthető oka, hogy az általuk használt lista kevés SJR-s folyóiratokat tartalmaz.

Ezzel szemben a média- és kommunikációs, a politika- és szociológiai tudományokkal foglalkozó oktatók szívesebben publikálnak olyan GJO listás folyóiratokba, amelyek egyben SJR Q-s listásak is (3. táblázat).

A vizsgált intézmények publikációs szokásaiból kiindulva megállapítható, hogy a gazdaságtudománnyal foglalkozó kutatók több mint 70\%-ban olyan indexált folyóiratokat választanak, amelyek SJR által is rangsoroltak (4. táblázat).

\section{Következtetések}

Tanulmányunkban a módosított egyetemi tanári pályázat publikációs követelménye változásának lehetséges következményeit vizsgáltuk a társadalomtudományok területén müködő magyarországi egyetemek oktatóinak publikációs tevékenységén keresztül.

$\mathrm{A} z$ intézményi adatokból kitünik, hogy az állam- és jogtudományokkal, a közigazgatástudományokkal, a média- és kommunikációs tudományokkal, a politikatudományokkal és a rendészettudományokkal foglalkozók számára jelent nagy segítséget ez a változtatás a minimális feltételek teljesítésében, mivel elsődlegesen a Gazdaság-és Jogtudományok Osztálya (GJO) által megadott A, B, C és D kategóriás folyóiratokban publikáltak az ezen a területen kutató oktatók. A szociológiai tudományokkal foglakozók számára nincs akkora jelentősége ennek a módosításnak, mert az általuk használt folyóiratlista közel 100\%-ban szinkronban van az Scimago Journal Rank (SJR) Q1, Q2, Q3, illetve Q4 besorolású listájával. Hasonló közvetkeztetések vonhatók le a gazdaságtudománnyal foglalkozó kutatókkal kapcsolatban is.

Amennyiben azt nézzük meg, hogy a vizsgált intézetekben melyik GJO-s folyóiratok a leggyakrabban használtak, akkor hasonló eredményekre juthatunk: az állam-, jog-, nemzetközi- és rendészettudományi karok oktatói 26\%-ban, a közgazdaság- és gazdaságtudományi karok kutatói 71\%-ban, a társadalomtudományi karok pedig - az SZTB listát használók túlsúlya miatt - 84\%-ban publikáltak olyan nemzetközi GJO folyóiratokban, amelyek az SJR Q-s listán is szerepelnek.

A nemzetközi rangsorokhoz Scopus által indexált közleményekre, azon belül SJR listás folyóiratcikkekre és hivatkozásokra van szükség. Ez a legfontosabb paraméter a rangsorképzésben (Csóka-Neszveda-Sebestyén 2019; Kosztyán et al. 2019; Kovács 2020). (3. ábra.) Mivel nem kötelező a társadalomkutatók számára, hogy írjanak SJR listás közleményeket, ezért megnő annak az esélye, hogy a nem SJR listán szereplö folyóiratokba publikáló kutatók nem tudják segíteni saját intézményüket kedvezőbb rangsorhelyek elérésében. A módosított egyetemi tanári pályázat publikációs minimum követelményének a változása - a GJO listáján levő folyóiratokba való publikálás elfogadása miatt - kedvező döntés a társadalom- és gazdaságtudománnyal foglalkozó karokról pályázók számára, de ez hosszabb távon nehézségeket jelenthet az intézmények, karok számára például a nemzetközi rangsorok elérésében.

Amennyiben a GJO nemzetközi listáit elemezzük, akkor látható, hogy csak a folyóiratok - pl. ÁJB és HTB listák esetén - egy része indexált SJR szerint. Holott az egyszerre 


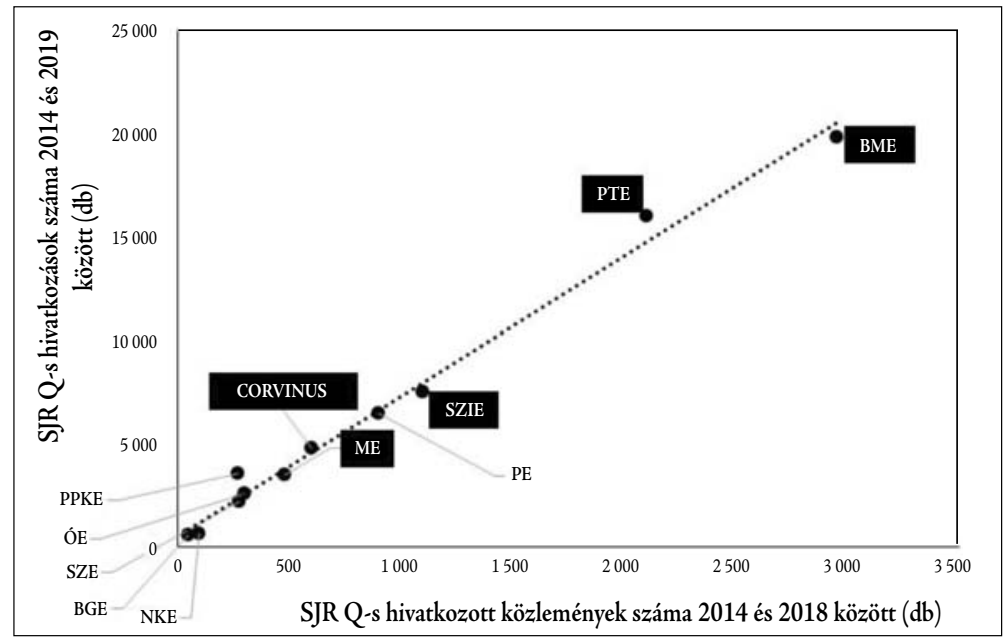

3. ábra: Quacquarelli Symonds (QS) nemzetközi rangsor 2020-as listájára felkerült egyetemek helye a közlemények száma és az azokra érkezett hivatkozások alapján. Forrás: MTMT

GJO és SJR listás közleményekről elmondható, hogy jóval nagyobb átlagos hivatkozással kecsegtetnek, ami hosszabb távon motivációt is jelenthet az oktatók, kutatók számára. Alapvető kérdés tehát, hogy miként tudja motiválni a társadalomtudomány területen kutató oktatókat a felsöoktatási intézmény vezetése arra, hogy a nemzetközi rangsorképzés szempontjából fontos SJR Q-s folyóiratokba publikáljanak, ha az egyéni előmenetelhez nem kötelező elem az SJR lista használata?

\section{IRODALOM}

Bazsa Gy. (2017) Felfelé a pályán. Hazai oktatói-kutatói karrierállomások. Magyar Tudomány, Vol. 178. No. 5. pp. 594-606.

Csóka I., Neszveda G. \& Sebestyén G. (2019) Tudományos teljesítmény mérése a magyar felsőoktatás gazdasági képzéseiben. Közgazdasági Szemle, Vol. 66. No. 7. pp. 751-770.

Dовоs I., Michalkó G. \& Nováky E. (2016) Miért nincs királyi út a habilitáció publikációs követelményeinek meghatározására? Magyar Tudomány, Vol. 177. No. 11. pp. 13791390.

KIss, É. (2014) A tudományos minősítés nemzetközi gyakorlata egy kérdőíves felmérés tükrében. Magyar Tudomány, Vol. 175. No. 9. pp. 1129-1135.

Kosztyán Zs. T., Banász Zs., Csányi V. V. \& Telcs A. (2019) Felsőoktatási ligák, parciális rangsorok képzése biklaszterezési eljárásokkal. Közgazdasági Szemle, Vol. 66. No. 8. pp. 905-931.

Kovács E. (2020) Amit elrejtenek a felsőoktatási intézmények rangsorai. Szigma, Vol. 51. No. 2. pp. 95-113.

Kozma T. (2011) „Egyetemvállalat” és menedzserizmus. Educatio, Vol. 20. No. 4. pp. 361471.

MAB (2020) Útmutató egyetemi tanári pályázat összeállitásáboz és értékeléséhez (A MAB Testületének 2020/6/IV/2. számú határozatával módosított, 2019/5/VII/4. számú Testületi határozattal elfogadott Útmutató egyetemi tanári pályázat összeállításához és értékelésé- 
hez címü dokumentum, a módosításokkal egységes szerkezetben). https://www.mab. hu/wp-content/uploads/2020/06/Egyetemi-tan\%C3\%A1ri-\%C3\%BAtmutat\%C3\%B3korrekci\%C3\%B3val-egys\%C3\%A9ges-szerkezetben.pdf [Letöltve: 2020. 08. 10.]

Polóny I. (2010) Az akadémiai szféra és az innováció - a bazai felsőoktatás és a gazdasági fejlödés. Budapest, Új Mandátum Könyvkiadó.

Sasvári P. \& Urbanovics A. (2019) Merre tovább egyetemi tanárok, avagy az új publikációs minimum aspektusai a társadalomtudományban. In: Karlovitz, J. T. (ed.) Újitások és újdonságok. Grosspetersdorf, Ausztria, Sozial und Wirtschafts Forschungsgruppe. pp. 5-30.

Soós S. (2017) Az impaktfaktor után - mi történik a hazai tudományos kibocsátással a Scimago Journal Rank bevezetésével? Hatások az „impaktfaktoros” publikációk körében. Magyar Tudomány, Vol. 178. No. 5. pp. 583-593.

Wuchty, S., Jones, B. F. \& Uzzi, B. (2007) The Increasing Dominance of Teams in Production of Knowledge. Science, Vol. 316. Issue 5827. pp. 1036-1039.

ZALAI E. (2006) Az MTA doktora címre pályázók habitusvizsgálatának értékelése, 2001-2005. Közgazdasági Szemle, Vol. 53. No. 4. pp. 380-386.

\section{Melléklet}

1. táblázat: A gazdaságtudomány területén „elismertnek” tekintett kiadók

\begin{tabular}{ll}
\hline 1) Addison-Wesley & 43) M.E.Sharpe Inc. \\
2) Akadémiai Kiadó & 44) Macmillan/Palgrave Press \\
3) Allen and Unwin & 45) Marcial Pons \\
4) Ashgate/Avebury & 46) McGraw-Hill \\
5) Aspen & 47) Methuen \\
6) Basic Books, Inc. & 48) MIT Press Cambridge Mass \\
7) Berg, Oxford & 49) Oxford University Press \\
8) Blackwell & 50) Palgrave McMillan \\
9) Bloomsbury & 51) Pearson \\
10) Brill & 52) Pennsylvania University Press \\
11) Bruylant & 53) Pergamon Press \\
12) California University Press & 54) Permanent Black/Orient Longman \\
13) Cambridge University Press & 55) Pluto Press, London \\
14) Cameron May & 56) Polity Press \\
15) Clarendon Press & 57) Praeger \\
16) Columbia University Press & 58) Princeton University Press \\
17) Cornell University Press & 59) Random House Inc, NY \\
18) Curzon Press & 60) Routledge Cavendish \\
19) Duke University Press & 61) Routledge Curzon \\
20) Earthscan & 62) Rowman and Littlefield Publishers \\
21) Edward Elgar & 63) Rutgers \\
\hline
\end{tabular}


1. táblázat: (folyt.)

\begin{tabular}{ll}
\hline 22) Elsevier Science & 64) Sage Publications \\
23) Frank Cass & 65) Scholar's Press \\
24) Garrisberg MacMillan & 66) Simon \& Schuster \\
25) Harcourt Brace Jovanovich, Inc. & 67) Springer \\
26) Harper \& Row Publishers, Inc./ & 68) St. Martin Press \\
Ballinger Publishing Co. & 69) Stanford University Press \\
27) Hart & 70) State University of New York Press \\
28) Harvard University Press & 71) Suhrkamp Verlag \\
29) Harwood Academic Publishers & 72) Swets Blackwell \\
30) Heinemann & 73) Taylor \& Francis \\
31) IWA publishers & 74) Texas University Press \\
32) James Currey & 75) Thompson Learning \\
33) John Wiley & 76) Thomson - Sweet \& Maxwell \\
34) John's Hopkins Univ. Press & 77) University of Chicago Press \\
35) Jossey-Bass & 78) University of Pennsylvania Press \\
36) Karthala & 79) Verso \\
37) Kegan Paul International & 80) Westview Press \\
38) Kluwer Academic Publishers & 81) Wiley \\
39) Lawrence Erlbaum & 82) Yale University Press \\
40) Lit Verlag & 83) Zed Books \\
41) Longman & \\
42) Lynn Rienner &
\end{tabular}

A cikk a Creative Commons Attribution 4.0 International License (https://creativecommons.org/licenses/ by/4.0/) feltételei szerint publikált Open Access közlemény, melynek szellemében a cikk bármilyen médiumban szabadon felhasználható, megosztható és újraközölhetö, feltéve, hogy az eredeti szerző és a közlés helye, illetve a CC License linkje és az esetlegesen végrehajtott módosítások feltüntetésre kerülnek. (SID_1) 